\title{
BRIEF CONSIDERATIONS ON BUSINESS VALUATION METHODS ${ }^{1}$
}

\author{
BREVES CONSIDERACIONES ACERCA DE LOS MÉTODOS DE VALORACIÓN DE \\ EMPRESAS
}

BREVES CONSIDERAÇõES SOBRE OS MÉTODOS DE VALORIZAÇÃO DE EMPRESAS

Por: RIASCOS HERMOZA_ Julio César, MOLINA_ Jesús Enrique

\begin{abstract}
Director of the Center for Regional and Business Development Studies at the University of Nariño. Economist, Master in Financial Management and Advisory. Econometrics Professor University of Nariño. GIDER Research Group, CES Research Group and Frontera Sur Research Group. Email: jriascos2009@hotmail.com, Colombia.
\end{abstract}

Doctoral student in Management, Universidad de Los Andes. Economist, Master in Financial Management, EAFIT University. Email: jemolinam2003@yahoo.com.ar, Colombia.

Recibido: 16 de agosto de 2016

Aprobación definitiva: 15 de julio de 2017

DOI: http://dx.doi.org/10.22267/rtend.171802.83

\begin{abstract}
Nowadays, determining the value of a business has gained significant importance in academic and business fields, as the understanding of the value of an organization has become a key tool for the management and marketing of a business. Accordingly, numerous methods have been developed in order to perform these kinds of practices.

In this article, the most used and current methods in processes of business evaluation are revised, observing their strengths and weaknesses, with the aim of comparing them and determining that the discounted cash flow methods are the most adequate procedures to perform this type of analysis.
\end{abstract}

Keywords: valuation methods, business valuation, discounted cash flows.

JEL: G12.

1 Special thanks to Loan Bedwyr, Andrea Ortega and Jhon Reyes for the contributions to the style correction of this article. 


\begin{abstract}
RESUMEN
Actualmente, estimar el valor de una firma ha cobrado una importancia significativa en los campos académico y empresarial debido a que conocer el valor de una organización se convierte en una herramienta clave para la administración y comercialización de la misma. De acuerdo con lo anterior, se han desarrollado numerosos métodos para llevar a cabo este tipo de ejercicios. En el presente artículo se revisan los métodos más utilizados en los procesos de valoración de empresas y se resaltan sus fortalezas y debilidades con el fin de compararlos y concluir que los métodos más robustos para llevar a cabo este tipo de análisis son los de flujos de caja descontados.
\end{abstract}

Palabras clave: métodos de valoración, valoración de empresas, flujos de caja descontados.

JEL: G12.

\title{
RESUMO
}

Atualmente, estimar o valor de uma empresa ganhou importância significativa nos domínios académico e empresarial, porque eles sabem o valor de uma organização torna-se uma ferramenta fundamental para a gestão e comercialização do mesmo. De acordo com o acima, vários métodos têm sido desenvolvidos para levar a cabo este tipo de exercício. Neste artigo, o mais utilizado no processo de avaliação de empresas e os seus pontos fortes e fracos são destacados, a fim de comparar e concluir que os métodos mais robustos para realizar este tipo de métodos de análise são os fluxos de caixa descontados.

Palavras-chave: métodos de avaliação, as empresas de rating, métodos de valorização de negócios.

JEL: G12.

\section{INTRODUCTION}

Business valuation plays an important role in the development of the financial theory and its application in the market. It estimates the value of an organization, becomes a fundamental exercise that will help business managers to determine which financial strategy to follow, provides stakeholders with an overview about the financial situation and the expectations of the organization moving forward. However, over the years, many business valuation methods have been developed. These methods do not necessarily produce a unique result. Consistent with the above, it is relevant to review the most popular and currently-used valuation methods.

This article, divided into five sections, revises these valuation methods in order to determine which are the most ideal. In the first section, the accounting methods are revised, by going into detail on the valuation methods through the balance sheet and those methods based on the construction for multiples. In the second section, mixed methods are researched. The third part delves into the methods that incorporate future business 
profitability in the business valuation practices. Fourth section, the discounted cash flow methods will be reviewed. Finally, at fifth part, reasons whereby the discounted cash flow methods are discussed as the most coherent and consistent methods.

\section{ACCOUNTING METHODS}

As its name suggests, in order to estimate the business value, these types of methods are based exclusively on the accounting information available excluding other significant elements in the development of these practices.

The advantages associated to this type of methods consist in the facility and speed to estimate the business value estimation. Nevertheless, these methods present shortcomings as they do not incorporate information associated with the possible performance of the firm in the future, concepts related to the time-value of money. Besides, they exclude asset classes beyond the accounting information of the organization, for instance, the goodwill or the experience of the business in its field of action. In this method, groups protrude the balance sheet and multiple methods.

\section{a. Balance sheet methods:}

Balance sheet methods are valuation methods which use the balance sheet information of the organization as the unique source to estimate the business value. The most prominent methods of this group are mentioned below.

\section{a.1. Book value method:}

This method emphasizes on the fundamental accounting equation, equating the firm value with the owner's equity of the organization. This value can also be obtained by subtracting the total liabilities from the total assets of the business.

\section{a.2. Adjusted book value method:}

This method corresponds to the book value method reviewed above. In this case, however, the business value estimation is calculated by adjusting the assets and liabilities value to their market value.

\section{a.3. Liquidation value method:}

This method incorporates the assumption that the firm will stop developing its operations at the moment of being sold. The business value estimation will focus on, and determine how much would be obtained if the Company was sold. 


\section{a.4. Replacement value method:}

This method, also known as "substantial value method", equates the business value to the cost incurred by the purchaser, if they decided to constitute a business with the same characteristics of the firm that is being valuated.

\section{a.5. Net real asset:}

This method is similar to the book value method, but aims to adjust the owner's equity to the most realistic value. It means that through this method, the business value corresponds to the assets which are susceptible to exploitation without the current liabilities of the firm at market prices.

\section{b. Valuation multiples:}

This method estimates the value of a determined firm (B) based on the calculation of a ratio or multiple in a group of similar organizations. Hence, a multiple regarding the organization $\mathrm{A}$ is calculated according to the expression below:

\section{Multiple A= transaction amount organization $A /$ indicator organization $A$} (Equation 1)

The transaction amount for business A corresponds to the price that was agreed on, based on the selling of a similar company. For instance, if a similar Company was sold for 2 million dollars two months ago, the transaction amount for the organization A will be exactly the same. On the other hand, the indicator for firm A will correspond to one of the entries in the earnings report, for example: sales, profits, etc.

The aim of the previous calculation is to build a ratio between the Price of a similar firm to the one that is being analyzed, and one of the key components of its financial statements. Therefore, this will become a tool for the examiner to apply in valuation of the firm $\mathrm{B}$ according to the following expression:

\section{Value firm $B=$ Multiple firm $A^{*}$ Indicator firm $B$.}

(Equation 2)

Furthermore, the construction of multiples can be developed either based on the information of similar organizations in the stock exchange, or analyzing the information of recent transactions of similar corporations to the firm that is being valuated.

The advantages of multiple valuation lie in the ease and speed of this type of method and in the sector information that is used to perform the valuation of the firm that is being analyzed. However, it is relevant to consider that this analysis does not take into account the information related to future performance of a business. It does not include concepts related to the time value of money and the value of others, such as goodwill or 
the experience of the firm in the sector, which are elements that are not reflected in the financial statements of corporations.

This group of methods protrude from those which use multiples as PER (Price Earnings Ratio), value of the firm in regard to EBITDA (Earnings Before Interest, Taxes, Depreciation and Amortization), EBIT, Net profit, free cash flow, etc. In each one of these proposals, the methodology applied is similar to the one exposed in equation 1 and 2, but takes into account that the indicator, used to calculate the value of the firm, will change according to each one of the methods mentioned above.

\section{Mixed methods valuation:}

As the title suggest, these methods aim to incorporate two elements in the valuation of an organization. Firstly, it includes an accounting component, implying that it is common to use the book value or the adjusted book value. The second valuation component is related to the goodwill that is determined by other criteria which differ from those revealed in the financial statements of the firm. Some of these elements attempt to incorporate representative elements to the business value, such as the experience of the organization in its sector and its advantages over competitors. Thus, the value of a firm calculated through a mixed method will correspond to the expression below:

\section{Business value $=$ book value+ Goodwill}

(Equation 3)

On the other hand, the goodwill is calculated through the following expression:

\section{Goodwill= net benefit ${ }^{*}$ sector multiplier \\ (Equation 4)}

Despite the fact that these methods include an accounting component which can be calculated efficiently, it is important to point out that their main weakness is that the sector multiplier does not present clear parameters for its calculation, resulting in an unreliable construction of the numerical approach made regarding goodwill. It is therefore not possible to generate, in most cases, a consistent output in the practices in which these methods are used.

Although many methods have been developed based on the mixed methods of valuation, some of the most relevant models are listed below: Classic, Experts Union, short rent, etc. These methods present some variations from the model exposed previously, without exhibiting any substantial difference in its intrinsic calculation.

\section{c. Discounted flow methods:}

The methods encompassed within this group are currently the most commonly used methods and, are also the most accepted methods in both the academic and business 
community. Generally, these methods "try to determine the firm value through the estimation of the cash flows that will be generated in the future, and then discounting them an at appropriate rate according to the risk of such flows" (Fernández, 2008: 14).

The methods that are included in this group constitute an exercise in which incorporates different tools to allow an adequate, complete and dynamic analysis of the value of the organization. Therefore, this type of analysis represents multiple advantages related to the following factors. Firstly, the value estimation of the organization is originated in its capability to generate funding in the future, and it does not imply a static analysis based exclusively on the performance of the firm in the past, as in the case of other methods explained earlier, such as accounting methods and valuation multiples.

Secondly, the purpose of this analysis is to incorporate a risk element through the discount of the flows at an appropriate rate, which includes a spread pertaining to the risk assumed by the firm actors in the development of the business operations. This marks a relevant difference regarding accounting valuation methods which do not include this element in an explicit or implicit way and it is also different from valuation multiples which do not include this element explicitly.Thirdly, although it is evident, it should be pointed out that these methods include the time value concept. This is relevant given that it allows a dynamic valuation in which an intertemporal analysis of investments can be made.

Finally, the business valuation through these methods includes a previous analysis of the firm context. Hence, it is important to point out that the starting line to estimate the value of an organization through discounted cash flow methods is to conduct a detailed review of the environment in which the organization operates. This is due to the fact that the knowledge and the understanding of the industry and economy that surrounds the firm are determinants to establish the conditions of the valuation exercise in terms of forecasts and value drivers. In accounting methods, these elements are not covered, whereas in valuation multiples and mixed valuation methods, this analysis should be done in an exhaustive form in order to ensure a reliable valuation practice.

The lack of speed and complexity of these methods are two factors that can be considered disadvantageous. The process of estimating the value of the organization should be as reliable as possible. Even though, in general terms the methodology of these methods follow general parameters in which flows are discounted through a certain rate, different proposals have been developed throughout time. Hence, some of the most used methods of this group are reviewed below in order to show a clearer idea of them.

\section{i. Discounted Cash flows through traditional WACC:}

In this method, the estimation of the firm value will correspond to the flow to be discounted, and the discount rate used to perform this practice. The flow to be discounted is the Free Cash Flow (FCF) and the rate used to discount it is the WACC, calculated through the traditional form. Therefore, the value of the firm will correspond to the expression below: 


$$
F V t=\frac{F C F(t+1)}{(1+W A C C(t+1))}+\frac{F C F(t+2)}{(1+W A C C(t+2))^{2}}+\ldots+\frac{F C F n}{(1+W A C C)^{n}}
$$

(Equation 5)

Where:

$\mathrm{FV} t=$ Value of the firm period $\mathrm{t}$.

FCF $(\mathrm{T}+1)=$ Free cash flow period $\mathrm{t}+1$.

FCFn= Free cash flow period $n$.

WACC $t+1=$ Weighted average Cost of capital period $t+1$.

In this case, the WACC calculation will be obtained from the following expression:

$$
W A C C=K e *\left(\frac{D}{F V}\right)+K d *\left(\frac{E}{F V}\right)
$$

(Equation 6)

Where:

Ke: Equity cost.

E/FV: Percentage share of equity in the firm value.

$\mathrm{D} / \mathrm{FV}$ : Percentage share of debt in the firm value.

Kd: Debt cost.

The Weighted average cost of capital (WACC) offers a clear outlook about the funding cost of the firm either from internal or external sources, for instance, banks. Concisely, the cost of capital of an organization corresponds to the average cost of total resources used by the firm taking into account the charged or required interest of all the parties that fund the operation of the organization weighted by the share of each one of the types of debt in its total financing. In other words, the aim of the WACC is to estimate "the required return over the operative assets of the firm" (Cooper, Davydenko, 2001, 2). Therefore, the WACC of any business would be the calculation of the average cost of the firm taking into account its capital structure.

Likewise, Vélez Pareja (2006) proposed another way for calculating WACC according to the expression below:

$$
W A C C=K e(t) * \frac{E(t-1)}{F V(t-1)}+K d(t) *(1-T) * \frac{D(t-1)}{F V(t-1)}
$$

(Equation 7) 
Where:

$\operatorname{Ke}(\mathrm{t})$ : Equity cost in period $\mathrm{t}$.

(E/FV) ( $t-1)$ : Percentage share of equity in the firm value period $t-1$.

$(\mathrm{D} / \mathrm{FV})(\mathrm{t}-1)$ : Percentage share of debt in the firm value period $\mathrm{t}-1$.

$\mathrm{Kd}(\mathrm{t})$ : Debt cost in period $\mathrm{t}$.

T: Tax rate.

In addition, for an appropriate calculation of the firm WACC, it is relevant to check the way in which Ke and Kd are calculated. This should be a complex task, but it requires special attention and understanding of the concepts used for this purpose, as these calculations could greatly influence the output of the valuation exercise.

Regarding the construction of debt cost, it is relevant to include the liabilities of the firm with all the external sources of financing, particularly those corresponding to financial debt. To achieve this objective, the analyst should follow the instructions below. First of all, it is important to dispose of the financial liabilities for each one of the forecasted years in the valuation. If the firm has multiple financial liabilities, this calculation will be related to the total sum of all of them. Secondly, it is necessary to calculate the total amount of interest that the company pays for financial liabilities for each period. The debt cost will be obtained by dividing the total interest on the total financial liabilities for each year provided in the valuation according to the following expression:

$$
K d(t)=\frac{\text { Interests }(t)}{\text { Debt Residue }(t-1)}
$$

(Equation 8)

As it can be seen in the last equation, the debt cost is calculated for each period, thus, it could be different for each year depending on the agreed conditions for the financial liabilities. Frequently, analysts make mistakes using a weighted average cost of the different financial liabilities rates of the firm which could lead to miscalculations as a consequence of working with a single debt cost for all the analyzed period.

On the other hand, the construction of the equity cost corresponds to the expected return by the firm owners as a result of the investment in the business. It is relevant to note that Ke is an expected rate, hence, it does not constitute an inexorable obligation for the business management, at least for the period of time that the board of directors consider suitable. This rate should be high enough to overcome other alternatives in which investors could participate, and offer a compensation for the risk assumed in the development of the firm operations. The following expression illustrates the calculation of the equity cost:

$$
K e(t)=K u(t)+(K u(t)-K d(t)) * \frac{D(t-1)}{E(t-1)}
$$

(Equation 9) 
Where:

Ke $(t)=$ Equity cost in period $t$.

$\mathrm{Ku}(\mathrm{t})=$ Equity cost without debt period $\mathrm{t}$.

$\operatorname{Kd}(\mathrm{t})=$ Debt cost period $\mathrm{t}$.

$\mathrm{D}(\mathrm{t}-1)=$ Debt value period $\mathrm{t}-1$.

$\mathrm{E}(\mathrm{t}-1)=$ Equity value period $\mathrm{t}-1$.

In the last equation it is possible to observe that the calculation of Ke includes the Equity Cost without debt in the period t, plus a Premium risk between the Equity Cost without debt and the debt cost. The third part of the equation corresponds to debt division on equity that performs as a risk indicator which depends on the capital structure of the firm. This ratio illustrates that the higher the debt in respect to the equity, the higher the expected equity cost. This conclusion is reasonable considering that normally, a high amount of debt in the capital structure of a firm could be perceived as a risky investment. The higher debt level causes investors to interpret it as a higher risk level, consequently, they demand to increase their profitability requirements to the firm (Sarmiento \& Cayón; 2005).

Another expression corresponding to $\mathrm{Ku}$ is required for the construction of $\mathrm{Ke}$. It is possible to calculate this rate according to the following:

$$
\boldsymbol{K u}=\boldsymbol{R} \boldsymbol{f}+(\boldsymbol{R m}-\boldsymbol{R} \boldsymbol{f}) * \boldsymbol{\beta}(\boldsymbol{d})
$$

(Equation 10)

The calculation of $\mathrm{Ku}$ is conducted through the model CAPM, which is coherent given that $\mathrm{Ku}$ corresponds to "what owners expect to receive from equity if business would not have financial debt" (Velez Pareja, 2006: 15). The firm owners, in this case, will not accept a rate inferior to the free risk rate, because they would obtain the same profitability investing their resources at this rate. Moreover, they will demand a risk Premium, which can be assumed as the difference between the market rate and the risk free rate. This result is multiplied by a coefficient beta, which pretends to incorporate a risk measure related to the firm activity. In this case, an unlevered beta coefficient is used with the purpose of capturing the risk related to the organization funding through proper resources. "Debt level affects the risk conditions, hence betas calculated for each Company depends on its indebtedness" (Sarmiento, Cayón; 2005: 3). Is possible to calculate the unlevered beta through the following expression:

$$
\beta_{u}=\frac{\beta_{c}}{1+(1-t) \cdot D / E}
$$

(Equation 11) 
Where:

$\beta_{\mathrm{u}}$ : Unleveraged beta.

$\beta_{c}$ : Leveraged beta.

T: Tax rate.

D/E: Capital structure of the firm.

On the other hand, free cash flow is defined as the cash flow generated by an organization available for the payment of the firm creditors (either shareholders or debtors). Similarly, free cash flow will correspond to a measure of the capacity of the firm to generate resources in a specific period. For the calculation of FCF, it is possible to use different methods obtaining the same result. In this article, the expression used to calculate FCF is below:

$$
F C F=I C F+O C F
$$

(Equation 12)

Where:

FCF: Free Cash Flow.

ICF: Investment Cash Flow.

OCF: Operational Cash Flow.

In the expression above, it is possible to observe that FCF constitutes the funds generated by the firm from its operations. Therefore, it is possible to infer that FCF of the organization is composed by adding the ICF to the OCF, as these measurements represent the generation of wealth by the firm generated by its operation given its investments needs.

The Operational cash flow summarizes all the incomes and expenses of the firm operations. In contrast, the ICF constitutes whether the initial and periodical investments required by the firm to perform its operations in the analyzed period.

\section{ii. Capital cash flow discounted through Ku:}

In the estimation of the value of the firm through this method, the Capital Cash Flow (CCF) is discounted through the equity cost without debt $(\mathrm{Ku})$. In this case, the calculation of the firm value will be given by the following expression:

$$
F T t=\frac{F C C(t+1)}{(1+K u(t+1))}+\frac{F C C(t+2)}{(1+K u(t+2))^{2}}+\ldots+\frac{F C C n}{(1+K u)^{n}}
$$

(Equation 13) 
Where:

FTt; Firm value in period t.

FCC $(\mathrm{T}+1)$ : Capital cash flow period $\mathrm{t}+1$.

$\mathrm{Ku}(\mathrm{t})$ : Equity cost without debt period $\mathrm{t}$.

Starting from the expression above, CCF is defined as all the available resources to comply with the financial liabilities that the firm has with external creditors and the distribution of dividends to shareholders. Hence, the CCF is equal to Debt Cash Flow (DCF) plus the shareholder cash flow according to the expression below:

$$
C C F=D C F+S C F
$$

(Equation 14)

Where:

CCF: Capital cash flow.

DCF: Debt cash flow.

SCF: Shareholder cash flow.

The shareholder cash flow corresponds to the cash flow generated by the firm before distributing dividends, but after Company debt has been paid. This means that the cash flow is generated by the organization and its management can use to distribute dividends to shareholders after the liabilities fulfillment.

The shareholder cash flow is determined by the dividends distributed by the firm and the possible sale that the shareholder could conduct as part of its participation to the organization. SCF is formed by the invested capital in a business in the present, for istance, capital goods or financial assets (expenditures) in order to generate capital inflows in the future from derived from the project (incomes). The algebraic sum of these items is the SCF" (Velez Pareja, 2006).

Therefore, cash flow debt is determined by all flows that should leave the company to comply with the payment of the debt that the organization has with external creditors. In general, the construction of this flow is similar to an amortization table, but considers all the loans that the firm has with external creditors and uses the appropriate interest rate for each of the obligations of the Company. DCF is constituted by the capital loaned by third parties (financial institutions) at a determined interest rate, this implies a payment or an expenditure for the entrepeneur, who makes it with the purpose of obtaining further incomes. The algebraic sum of these items is the DCF (Vélez Pareja, 2006). 


\section{iii. Equity value:}

In these methods, the firm value calculation is obtained by discounting the SCF through Ke and adding the debt residue to the result. The estimation of the firm value through this method is presented in the following expression:

$$
\begin{gathered}
F V t=\left(\left(\frac{S C F(t+1)}{(1+K e(t+1))}\right)+S D(t)\right)+\left(\left(\frac{S C F(t+2)}{(1+K u(t+2))^{2}}\right)+S D(t\right. \\
+1))+\ldots+\left(\left(\frac{S C F n}{(1+K u)^{n}}\right)+D R(n-1)\right)
\end{gathered}
$$

Where:

(Equation 15)

FVt: Firm value period $t$.

$\mathrm{Ke}(\mathrm{t}+1)$ : Equity cost period $\mathrm{t}+1$.

$\mathrm{Ku}(\mathrm{t}+1)$ : Equity cost without debt period $\mathrm{t}+1$.

$\mathrm{SD}(\mathrm{t})$ : Debt residue period $\mathrm{t}+1$.

The majority of terms in equation 15 are already known. The debt residue is the sum of all the financial liabilities of the firm for each one of the analyzed periods. According to Ehrhardt (1999) the SCF, can be understood as the amount available for the shareholder after covering the costs of capital investments and other expenses such as the payment of debt and taxes. In theory, the shareholder has the right to take that money form the Company in form of dividends, but in practice the reinvestment needs of the Company, tax factors (dividend), perceptions of dividend payments, and different needs in capital structure can all influence the shareholder's behaviour.

\section{iv. Adjusted present value:}

According to this method, the firm value corresponds to the following expression:

$$
V_{L}=V_{U}+t D
$$

(Equation 16)

Where:

$\mathrm{V}_{\mathrm{L}}=$ Firm value with debt

$\mathrm{V}_{\mathrm{U}}=$ Firm value without debt

$\mathrm{tD}=$ Present value of the tax savings by interests.

Starting from the last equation, the firm value is obtained through APV method, which corresponds to the sum of the value of the firm; here, the assumption is made that the 
business does not have debt, and that there is tax savings cash flow. The firm value is calculated without the effect of debt. This estimation is discounted by the FCF through the equity cost without debt $(\mathrm{Ku})$ according to the following expression:

$$
P F V u=\frac{F C F 0}{(1+K u)}+\frac{F C F 1}{(1+K u)^{1}}+\ldots+\frac{F C F n}{(1+K u)^{n}}
$$

(Equation 17)

Where:

$\mathrm{PFV}_{\mathrm{U}}$ : Present value of the firm without debt.

FCF0: Free cash flow period 0.

$\mathrm{Ku}$ : Cost of equity without debt.

At this point, it is relevant to state, firstly, that the calculation of FCF and Ku can be realized through the method presented in this article, as well as the estimation of the FCF. Secondly, it is indispensable to proceed to the calculation of the tax saving flow. The discount of this flow should be made through $\mathrm{Ku}$, since it is pretended to calculate the effect of the indebtedness of the company over its flows. This effect is a function of the interest and the tax rates that have been paid. This calculation could be made according to the expression below:

$$
P V T S F=\frac{T S C F_{0}}{(1+K u)}+\frac{T S C F_{1}}{(1+K u)^{1}}+\ldots+\frac{T S C F_{n}}{(1+K u)^{n}}
$$

(Equation 18)

Where:

PVTSF: Present value of tax saving flow. $\mathrm{TSCF}_{0}$ : Tax saving cash flow period 0.

$\mathrm{Ku}$ : Equity cost without debt.

\section{v. Adjusted WACC:}

The firm value estimation in this method requires the calculation of a WACC, different from what is generally used and which has been denominated as adjusted WACC. The calculation of this variable is described below:

$$
W A C C(\operatorname{adj})(t)=K u t-\frac{A I t}{F V(t-1)}
$$

(Equation 19) 
Where:

WACC (adj) (t): Adjusted WACC period t.

Kut: Equity cost without debt period $t$.

AIt: Tax saving period $t$.

FV (t-1): Firm value period $t+1$.

This method is more reliable than the traditional method to calculate WACC, since in this case the tax saving value is included as an absolute value and not as a lower value of $\mathrm{Kd}$ (Vélez Pareja, Tham 2012). The calculation of the firm value, in this method, corresponds to the following expression:

$$
\begin{aligned}
F V t=\frac{F C F(t+1)}{(1+W A C C \operatorname{adj}(t+1))} \\
\quad+\frac{F C F(t+2)}{(1+W A C C \operatorname{adj}(t+2))^{2}}+\ldots+\frac{F C F n}{(1+W A C C \operatorname{adj}(n))^{n}}
\end{aligned}
$$

(Equation 20)

Where:

FVt: Firm value period t.

FCF $(\mathrm{T}+1)$ : Free cash flow period $\mathrm{t}+1$.

WACCadj $(\mathrm{t}+1)$ Adjusted WACC period $\mathrm{t}+1$.

\section{d. Conclusions}

According to the advantages and disadvantages of the valuation methods reviewed, it can be seen that even though there are multiple methods that can be used to valuate a firm, the results obtained from their use present a wide range of differences which are not only reflected in the final value obtained through the valuation exercise, but also in the conceptual development throughout the stages of the valuation process. However, it is not possible to discount any of these methods as incorrect, considering that the use of them depends, in the majority of the cases, on the purpose for which the practice is conducted. For instance, the objective of a valuation exercise is not the same when the organization management is considering a merger, or an acquisition, compared to the practice performed to simply dispose of a reference value regarding the sector in which the firm develops its operations.

Likewise, there are methods conceptually more pertinent than others, and therefore, give more reliable results in a valuation exercise considering the way in which the method is performed. They allow for the incorporation of sophisticated tools, which provide the analyst with a reliable estimation of the firm value. In general, financial literature emphasizes that most methods are the discounted cash flow methods. "In these methods, the firm is considered as an entity capable to generate cash flows, and to obtain an outcome, the present value of those flows is calculated through an adequate discount rate. The value 
of the shares of a firm -supposing continuity - originated from the cash flow generation to the owners of the shares. Therefore, the most appropriate method to value a Company is to discount the expected future cash flows" (Fernandez, 2008).

In addition, these methods present many advantages. They are considered dynamic methods because the firm value depends on its capability to generate funds in the future, and it is not limited to performing a static analysis considering only the historic information of the organization. In the same line, these type of methods contemplate the economic context in which the business develops its activities and its potential performance in the future. These elements can be incorporated in the projections made to construct valuation models, as well as discount rates and the sector who the company belongs to. As a result, such methods are complete and conceptually correct to develop a valuation exercise. Accordingly, these firm valuation methods are considered suitable for its objectivity, which implies knowing the real firm value and its market offers based on the settlement of its value or its ability of generating, directly or indirectly, funds after its adquisition. These methods are not based on subjective perceptions by their owners or market potential buyers (Pereyra, 2008).

Finally, it is pertinent to reiterate that the reliability of the results obtained through a valuation exercise will largely depend on the analysis and the proper use of the chosen method. Simply performing a business valuation through a discounted cash flow method does not necessarily imply that the exercise is well developed. Quality depends on conceptual clarity and the assertiveness of the analyst to develop the exercise.

\section{REFERENCES}

(1) COOPER, Ian A. and DAVYDENKO, Sergei A. The Cost of Debt (March 8, 2001). Available at SSRN: https:// ssrn.com/abstract=254974 or http://dx.doi.org/10.2139/ssrn.254974

(2) EHRHARDT, M., DAVES, P. (1999). The Adjusted Present Value: The Combined Impact of Growth and the Tax Shield of Debt on the Cost of Capital and Systematic Risk. University of Tennessee.

(3) FERNÁNDEZ, P. (2008). Valoración de Empresas Cómo medir y gestionar la creación de valor. Barcelona, España: Gestión 2000.

(4) PEREYRA, M. (2008). Valoración de empresas. Revisión de los métodos actuales. Documento de Trabajo Nro. 41 Facultad de Administración y Ciencias Sociales, Universidad ORT Uruguay.

(5) SARMIENTO \& CAYON. (2005). Cálculo del costo del patrimonio desapalancado. Pontificia Universidad Javeriana. $1-33$.

(6) VÉLEZ PAREJA, I. (2006). Decisiones de Inversión para la Valoración financiera de proyectos y empresas. Bogotá, Colombia: Editorial Pontificia Universidad Javeriana.

(7) VÉLEZ PAREJA, I. THAM, J. (2012, 1 de Febrero), Una introducción al costo de capital. Tópicos en Valoración de Activos no financieros. Recuperado de http://papers.ssrn.com/sol3/papers.cfm?abstract_id=1997065. 